\title{
ADA APA DENGAN JILBAB? (SEBUAH PRAKTIK HEGEMONI MONOKULTURALISME DALAM INSTITUSI KEPOLISIAN)
}

\author{
Vellayati Hajad \\ Fakultas Ilmu Sosial Dan Ilmu Politik Universitas Teuku Umar
}

\begin{abstract}
This article discusses the issue of the monocultural and hegemony that occur in police forces, especially police women in Indonesia. Monokulturalisme related to the concept of cultural unification (homogentitas). In monokulturalisme, a sign of the assimilation process is a mixture of two or more cultures to form a new culture. As an ideology, monokulturalisme in some countries serve as the basic of government policies and strategies concerning culture and system state.
\end{abstract}

Keyword: Identity, Hegemony, Monokulturalisme 


\section{PENDAHULUAN}

Polisi wanita merupakan bagian integral dari kepolisian Republik Indonesia. Polisi wanita yang selanjutnya akan disingkat dengan polwan memiliki tugas untuk memelihara keamanan, ketertiban nasional, penegak hukum, memberikan perlindungan, pengayoman, dan pelayanan kepada masyarakat. Semboyan yang dimiliki oleh polwan adalah Esthi Bhakti Warapsari yang berarti bakti putri-putri pilihan menuju cita-cita luhur.

Pelayanan prima dari anggota polwan untuk seluruh masyarakat tanpa membedakan agama. Sedangkan di saat bersamaan pakaian dipandang banyak kalangan dapat menunjukkan identitas dan berpengaruh terhadap pelayanan yang diberikan kepada masyarakat. Wacana polwan berjilbab beberapa waktu belakangan ini pada akhirnya mendatangkan respon positif dan negatif dari berbagai pihak khususnya anggota polwan sendiri. Wacana publik tentang penggunaan jilbab berputar-putar pada pertanyaan "apakah jilbab simbol kesalehan atau penegasan terhadap identitas islam? Pada tahap ini jilbab masuk dalam tahap kontestasi pencarian makna.

Jilbab ternyata tidak dapat dilihat sebagai selembar kain penutup kepala sebagaimana makna asalnya. Selembar kain yang bagi perempuan lain dapat digunakan atau tidak digunakan tergantung pada keinginan si perempuan menjadi sama sekali berbeda apabila perempuan tersebut berada dalam institusi yang memiliki aturan baku dalam cara dan model berpakaian. Meskipun saat ini, penggunaan jilbab di kalangan militer seperti pada polisi perempuan telah disetujui namun sebelumnya terlah terjadi banyak perdebatan terkait persoalan selembar kain ini.

Ada berbagai kepentingan yang bermain dalam regulasi penggunaan seragam di dalam institusi kepolisian. Menggunakan jilbab atau tidak menggunakan jilbab bukan sekedar persoalan agama, lebih jauh dari itu, ada persoalan eksistensi diri, penguatan identitas, dan proses panjang pencarian makna personal yang ditunjukkan dari penggunaan seragam beserta seluruh atributnya. Dalam kajian ini, kita dapat menyebutnya sebagai praktek kuasa. Terdapat arena pertarungan bagi dominasi dan hegemoni kekuasaan dalam setiap aturan, kebijakan, dan regulasi di dalam sebuah institusi termasuk institusi kepolisian.

Penggunaan jilbab di kalangan polwan pada masanya dapat dilihat sebagai praktek kuasa yang dijalankan oleh institusi. Dimana sebagai sebuah struktur institusi kepolisian berhak untuk menciptakan aturan yang mengikat anggota-anggotanya yang merupakan agen untuk mematuhi semua aturan yang diberikan. Dominasi atas nama menjaga kultur institusi ini telah berjalan puluhan tahun, sama tuanya dengan negara Indonesia dan dijaga melalui sanksi atau teguran bagi agen yang berani melawan struktur.

Menurut Crawley pakaian adalah ekspresi yang paling khas dalam bentuk material dari berbagai tingkatan kehidupan sosial. Sehingga pada akhirnya jilbab menjadi sebentuk eksistensi sosial dan individu di dalam komunitasnya (El Guindi : 2003). Penampilan fisik seseorang dipengaruhi oleh nilai-nilai agama, kebiasaan, lingkungan, kenyamanan, dan bertujuan sebagai pencitraan. Seorang wanita beragama islam atau sering disebut sebagai muslimah memakai jilbab sebagai manifestasi ajaran islam dan sering dipandang oleh orang lain sebagai sebuah simbol agama.

George Hebert Mead memandang interaksi simbol berisi isyarat verbal dan non-verbal yang dimaknai berdasarkan kesepakatan bersama semua pihak yang terlibat. Seragam anggota polwan beserta semua atributnya merupakan isyarat non verbal yang dibentuk oleh kesepakatan bersama pada akhirnya akan mengantarkan isyarat kepada orang lain yang pada akhirnya mendatangkan respon positif dan negatif dari berbagai pihak dan berpengaruh terhadap kinerja dan pelayanan polwan dalam fungsinya sebagai pelayan masyarakat.

Pada awalnya penggunaan jilbab dipandang akan mempengaruhi profesionalitas polwan dalam menjalankan fungsi pelayanan kepada masyarakat oleh karena itu penggunaannya dilarang. Hal ini sesuai dengan pandangan Mead bahwa seragam polwan terutama jilbab sudah dimaknai sebagai sebuah simbol agama tertentu, dan penggunanya dianggap akan tidak netral 
dan berpihak pada agama yang dimaksud, yaitu Islam terutama ketika sedang bertugas di dalam masyarakat yang memiliki konflik dan berbeda agama.

Penggunaan jilbab di kalangan polwan menimbulkan banyak perdebatan. Penggunaan jilbab oleh polwan dipandang akan memberikan isyarat "keberpihakan" polwan terhadap golongan atau kelompok agama tertentu. Isyarat ini pada akhirnya akan menghalangi polwan untuk memberikan pelayanan yang maksimal kepada masyarakat. Padahal, pada dasarnya polwan dituntut untuk "netral". Netralitas posisi polwan ini adalah representasi negara yang netral dan tidak memihak. Sehingga polwan yang bergabung dalam kesatuan harus mematuhi berbagai peraturan yang telah disepakati terutama terkait penggunaan seragam dinas kepolisian ketika bertugas.

Adapun hal yang menarik adalah pernah terjadi fenomena polwan dilarang untuk berjilbab di beberapa daerah di Indonesia dan di sisi berbeda malah mewajibkan polwan berjilbab di Aceh. Pertanyaan besarnya adalah mengapa hal tersebut dapat terjadi? Ada hal besar apa yang melatarbelakangi fenomena tersebut? Sehingga hal ini menjadi menarik untuk didiskusikan kembali meskipun saat ini polwan telah diperbolehkan untuk berjilbab.

\section{METODOLOGI PENELITIAN}

Studi Ini menggunakan metode penelitan kualitatif dengan dengan pendekatan studi kasus pada polisi wanita. Metode studi kasus adalah sebuah metode pengumpulan informasi secara sistematis terhadap orang tertentu, pengaturan sosial, suatu peristiwa, atau memfokuskan perhatian pada kelompok sehingga memungkinkan peneliti untuk memahami masalah secara efektif terutama terkait cara beroperasi atau cara berfungsi (Berg : 2001). Lebih lanjut, studi kasus dapat digunakan untuk mengetahui dan memahami bagaimana penggunaan jilbab menjadi sesuatu yang menarik diamatai karena jilbab tidak sekedar menjadi selembar kain penutup kepala, namun lebih dari itu penggunaan jilbab dapat dilihat sebagai praktek permainan kuasa atas hegemoni multikulturalisme.

Metode studi kasus yang digunakan menggunakan sejumlah langkah pengumpulan data dari studi lapangan dan pustaka. Proses analisis data mengikuti Craswell (2007) yaitu mengorgnisir informasi, membaca keseluruhan informasi yang diperoleh, dan memberi kode untuk memudahkan analisis, membuat uraian terperinci mengenai kasus, menetapkan bentuk bentuk hegemoni yang terjadi dalam perdebatan penggunaan jilbab di kalangan polisi wanita.

Setelah data dan informasi terkumpul maka selanjutnya dilakukan interpretasi atas data dan fenomena yang terjadi yaitu telah terjadi kebijakan pelarangan dan kebijakan mengharuskan polisi wanita berjilbab di dalam tubuh institusi kepolisian. Dengan melakukan interpretasi maka tujuan dari penelitian dapat tercapai.

\section{PEMBAHASAN}

\section{Polisi Wanita Indonesia Dalam Perspektif Sejarah}

Polisi Wanita di Indonesia sudah ada di Indonesia sejak tahun 1948. Sebelum masa kemerdekaan atau tepatnya pada masa penjajahan Belanda apabila terjadi tindak kejahatan dan pelakunya adalah wanita atau anak-anak maka para pejabat kepolisian akan meminta bantuan kepada istri-istrinya untuk melakukan pemeriksaan dan penggeledahan. Namun demikian, setelah Indonesia merdeka, banyak wanita dari berbagai kelompok dan komunitas mengajukan permohonan kepada pemerintah dan kepolisian negara untuk mengikutsertakan wanita dalam pendidikan kepolisian guna menangani masalah kejahatan yang melibatkan anak-anak dan wanita.

Polwan lahir di Indonesia pada tanggal 1 September 1948 di Bukit Tinggi Sumatera Barat ketika pemerintah sedang menghadapi Agresi Militer II. Pemerintah Indonesia saat itu menunjuk SPN (Sekolah Polisi Negara) Bukit Tinggi untuk membuka Pendidikan Inspektur Polisi bagi kaum wanita. Namun demikian, pendidikan polwan ini pada akhirnya sempat 
terhenti karena Agresi Militer Belanda. Diawal pembentukannya pada tahun 1948 dalam susunan organisasi Polri memang belum terlihat pembinaan polwan secara khusus. Kini, untuk wadah pembinaan Polwan berada di bagian Polisi wanita yang bernaung dibawah Direktur Personil Polri dan Biropers untuk tingkat daerah.

Sejarah baru Polwan sebenarnya dimulai saat Jendral Anton Soedjarwo menjabat sebagai Kapolri dan Kapolda Jawa Timur dijabat oleh Mayjen Soedarmadji. Kedua pejabat Polri itu mengambil langkah berani dengan menempatkan beberapa orang Polwan pilihan untuk menempati jabatan strategis, sejak saat itu Polwan bukan hanya di percaya sebagai pemegang bidang tugas pembinaan tetapi juga memegang komando bidang operasional di lapangan. Bersamaan dengan itu sejumlah polwan berpangkat perwira menengah dipercaya mengemban tugas kekaryaan fungsi sosial politik di lembaga legislatif.

Polwan saat ini telah berusia 68 tahun, di usianya yang hampir sama dengan usia negara Indonesia, polwan sebagai bagian dari institusi kepolisian perlu melakukan berbagai perbaikan dan inovasi dari sisi kinerja dan layanan kepada masyarakat dan hal tersebut ditunjukkan dari semakin terbukanya kepolisian terhadap aspirasi anggotanya terutama dalam penggunaan seragam dan atribut seperti jilbab bagi polwan.

\section{Seragam dalam Frame Birokrasi Monokulturalisme}

Kymlicka di dalam bukunya yang berjudul Kewargaan Multikultural (2015) mengatakan bahwa konsep monokulturalisme berangkat dari asumsi bahwa perbedaan hanya akan menimbulkan perpecahan dan konflik. Oleh karena itu, perbedaan harus dihilangkan dengan cara menutup peluang bagi terbentuknya perbedaan yaitu dengan melakukan penyeragaman di dalam sebuah komunitas atau kelompok dan apabila di kemudian hari muncul perlawanan dari sekelompok kecil individu di dalam komunitas atau kelompok maka solusi yang paling ideal adalah dengan cara mengeluarkan mereka dari dalam komunitas. Hal itu harus dilakukan demi menjaga keutuhan komunitas.

Monokulturalisme berasal dari kata mono yaitu satu/seragam/tunggal dan cultural yang berarti budaya atau kebudayaan, dan isme yaitu paham. Secara etimologi monokulturalisme berarti paham budaya tunggal sehingga pada satu wilayah geografis tertentu hanya ada satu budaya yang dianut. Hal ini juga bermakna bahwa ingin menegasikan atau tidak mengakui adanya keberagaman dan menginginkan keseragaman dan homogenitas ditandai dengan adanya proses asimilasi beberapa budaya ke dalam satu budaya.

Polwan hadir di tengah masyarakat Indonesia sejak puluhan tahun yang lalu. Namun demikian, isu mengenai penggunaan jilbab bagi polwan baru menjadi perdebatan yang hangat ketika pemberlakuan otonomi khusus di Aceh pada tahun 2004. Otonomi khusus yang berlaku di Aceh berdampak pada "mewajibkan" polwan untuk menggunakan jilbab sebagai bagian dari seragam kedinasan terutama ketika polwan melakukan pelayanan kepada masyarakat. Selain itu, isu penggunaan jilbab juga kembali muncul ke permukaan ketika Soekarwo sebagai gubernur Jawa Timur pada tahun 2009 menghimbau polwan yang beragama islam untuk menggunakan jilbab sebagai refleksi bagi Provinsi Jawa Timur sebagai daerah santri.

Persoalan penggunaan jilbab di kalangan polwan semakin memanas ketika akhirnya muncul akun-akun dan pemberitaan di media sosial yang pada intinya memberikan dukungan bagi polwan yang ingin menggunakan jilbab. Melihat realitas pelarangan penggunaan jilbab bagi polwan maka kita melihatnya sebagai suatu bentuk monokulturalisme yang dipaksakan secara halus. Monokulturalisme ini diwujudkan dengan adanya keinginan untuk menyeragamkan entitas yang berbeda-beda dalam satu wujud yang serupa. Sedangkan, Indonesia merupakan negara dengan identitas masyarakat yang plural sehingga pelarangan penggunaan jilbab bagi polwan dapat dipandang sebagai bagian dari cara untuk membelenggu individu mengekspresikan identitas. Institusi kepolisian berusaha mewujudkan diri sebagai institusi yang 
netral dengan tidak memperlihatkan keberpihakan dan sebisa mungkin mewujudkan stabilitas sistem.

Mengacu pada definisi birokrasi milik Weber, organisasi Kepolisian merupakan bentuk institusi pemerintahan yang tidak jauh berbeda dengan institusi pemerintahan lainnya. Di dalam birokrasi secara umum, individu pejabat secara personal bebas namun di saat bersamaan juga dibatasi oleh jabatannya manakala ia menjalankan tugas-tugas dalam jabatannya. Demikian halnya pada institusi Kepolisian, setiap aparat penegak hukum memiliki kebebasan sebagai individu, tetapi tetap memiliki keterikatan ketika berada dalam korps kesatuannya atau ketika menjalankan tugas.

Jabatan-jabatan dalam institusi Kepolisian disusun secara hierarkis dari tingkat atas ke bawah tugas dan fungsi masing-masing jabatan dalam hierarki itu secara spesifik berbeda satu sama lainnya, karakter ini juga sama dengan birokrasi pada umumnya. Jika pada birokrasi lainnya setiap pejabat diseleksi atas dasar kualifikasi profesionalitasnya, pada institusi Kepolisian pun demikiaan adanya. Pasca reformasi, tepatnya pada tanggal 1 April 1999 Kepolisian Republik Indonesia berdiri sendiri sebagai institusi negara yang berperan sebagai penegak hukum, pembina ketertiban masyarakat, pelindung, pengayom, dan pelayan masyarakat (Pasal 13 UU No.2 Tahun 2002).

Dengan demikian, dalam monokulturalisme birokrasi, kebijakan pelarangan dan izin penggunaan jilbab bagi polwan menunjukkan adanya peleburan identitas yang disatukan dalam institusi organisasi formal. Dengan bahasa sederhana, pelarangan penggunaan jilbab ketika itu adalah tuntutan dari "keseragaman" sebuah institusi terjadi sebuah dominasi untuk mempertahankan kultur yang sudah dijaga selama puluhan tahun. Dengan demikian, institusi kepolisian menganggap penyeragaman adalah jalan bagi profesionalisme.

\section{Bentuk Kebijakan Jilbab: Hegemoni Sekuler Atas Perbedaan}

Teori hegemoni dalam jagad teori ilmu politik secara eksplisit diperkenalkan oleh Antonio Gramsci sebagai penjelasan atas teori kelas Marxisme. Dalam teori kelas Marxis, disebutkan bahwa formasi masyarakat kapitalis itu terdiri dari dua kelas, yaitu kelas memiliki kekuasaan "dominasi" dan kelas "sub-ordinasi" (Arif Budiman : 1996).

Kelas yang dianggap memiliki kekuasaan "dominasi" adalah kelas borjuis atau pemilik alat produksi. Sedangkan kelas yang dianggap "sub-ordinasi" adalah kelas proletar atau buruh. Eksistensi kelas borjuis Menurut faham marxisme dianggap mengeksploitasi kelas proletar dimana mereka bekerja untuk kelas borjuis sehingga kepemilikan modal dikuasai oleh kelas borjuis, sedangkan kelas proletar selamanya akan menjadi kelas buruh. Untuk memutus adanya dominasi kelas borjuis terhadap kelas proletar, maka dibutuhkan gerakan perlawanan fisik melalui revolusi sehingga menghasilkan formasi masyarakat tanpa kelas.

Teori ini cukup berhasil mempengaruhi gerakan revolusi kaum buruh di Eropa Timur seperti Uni Soviet. Meskipun begitu, gerakan perlawanan kaum buruh terhadap kaum borjuis di Eropa Barat seperti Inggris cenderung gagal. Kegagalan inilah yang menjadi titik tolak teori hegemoni Gramsci dalam menjelaskan kegagalan revolusi kaum buruh di Inggris disebebkan karena adanya hegemoni kapitalisme melalui suprastrktur ideologi di dalam kepemimpinan masyarakat sipil (Nezar Patria: 1999).

Konsepsi tentang hegemoni Gramsci merupakan sebuah kekuasaan dominasi antara satu kelompok yang "berkuasa" dengan kelompok yang "dikuasai". Dalam menjelaskan kekuasaan dominasi, Gramsci membedakan dominasi menjadi dua bentuk, yaitu dominasi langsung dan dominasi secara tidak langsung. Dominasi langsung diekspresikan melalui negara dan pemerintahan yuridis yang sifat mengikat dan memaksa. Sedangkan dominasi tidak langsung diekspresikan melalui kepemimpinan moral di masyarakat sipil. Kedua saluran dominasi tersebut dibingkai dalam satu konsepsi tentang negara, yaitu apa yang disebut oleh Gramsci sebagai "negara integral". 
Konsep negara integral dapat dibedakan dengan konsep totalitarianisme, karena dalam negara integral terdapat "kesukarelaan" yang tentunya tidak ada dalam konsep totalitarianisme. Di dalam konsep negara integral, diasumsikan adanya sebuah kesepakatan yang didasarkan atas seperangkat gagasan dan nilai, suatu falsafah bersama yang dimiliki oleh sebagian besar orang berdasarkan persetujuan yang aktif dan diberikan secara bebas (Robert Bocock: 2007).

Meskipun demikian, konsepsi negara hegemoni Gramsci dengan teori dominasi dapat dijadikan sebagai instrumen dalam membaca dominasi kelompok sekuler atas kelompok agama dalam aparatur negara. Konsepsi tentang negara sekuler sebenarnya telah inheren di dalam konsep negara modern di mana agama bukan lagi menjadi persoalan publik yang menjadi urusan negara, melainkan agama adalah persoalan privat yang menjadi urusan individu. Penerapan negara sekuler menjadi beragam tergantung sejauh mana pengaruh ideologi "sekularisme" berkembang di dalam suatu negara. Dalam paham sekularisme, seseorang melihat agama sebagai sesuatu yang asing, dan Tuhan dianggap sebagai pengahalang dan dianggap bertentangan dengan sains. (Pardoyo: 1993).

Negara sekuler menurut Gramsci dibagi dalam tiga tingkatan, yaitu hegemoni total (integral), hegemoni yang merosot (decadent) dan hegemoni yang minimum (Patria: 1999). Pertama, hegemoni total (integral) ditandai dengan afiliasi masa yang mendekati totalitas. Masyarakat menunjukkan tingkat kesatuan moral dan intelektual yang kokoh. Ini tampak dalam hubungan organisasi antara pemerintah dan yang diperintah. Hubungan tersebut tidak diliputi dengan kontradiksi dan antagonisme baik secara sosial maupun etis. Kedua, hegemoni yang merosot (decadent) ditandai dengan adanya tatntangan berat terhadap dominasi ekonomi borjuis. Meskipun sistem yang ada telah mencapai kebutuhan, namun mentalitas massa tidak selaras dengan pemikiran yang dominan dari subjek hegemoni. Ketiga, hegemoni minimum (minimal hegemony) merupakan bentuk hegemoni yang paling rendah dibanding dua bentuk sebelumnya.

Dominasi kekuasaan ini termanifestasi menjadi dua bentuk yaitu dominasi secara langsung maupun dominasi tidak langsung. Dominasi secara langsung diwujudakan melalui adanya peraturan yang menimbulkan ambiguisitas bagi individu anggota Polwan. Anggota Polwan diikat dengan beragam peraturan yang membatasi gerak langkahnya untuk menunjukkan identitas dirinya yang sebenarnya. Peraturan mengenai pelarangan penggunaan jilbab ini sebenarnya sudah dimulai ketika seseorang itu berkeinginan untuk menjadi bagian dalam kesatuan Bayangkari, berawal dari proses rekruitmen ini calon taruni (calon anggota Polwan) sudah mengetahui konsekuensi yang akan diterima ketika akan menjadi bagian dari institusi Polri, sehingga bila tidak berkenan bisa mudur dari awal. Dominasi ini kemudian diperkuat dengan tidak adanya aturan khusus bagi Polwan yang berkeinginan berjilbab, selain Skep/702/IX/2005.

Sedangkan dominasi tidak langsung diekspresikan melalui kepemimpinan moral di masyarakat sipil. Polwan merupakan bagian dari Kesatuan Kepolisian yang selalu diharapkan menjadi pengayom, pelindung, dan pelayan masyarakat. Untuk mewujudkan itu, sosok polwan selalu dikonstruksikan sebagai sosok perempuan yang tegas, menonjolkan maskulinitas, dengan ciri fisik berambut pendek, tinggi, dan sebagainya.Dengan kontruksi seperti ini Polwan diharapkan mampu menyampaiakan pesan-pesan moral, sebagai sosok pemimpin yang disiplin dan penuh integritas. Konstruksi identitas inilah yang sekiranya menjadi identitas tunggal yang dipaksakan kepada semua jajaran anggota polwan.

Peraturan itu secara umum membedakan adanya seragam umum dan seragam khusus bagi polisi. Seragam umum tersebut antara lain : pakaian dinas upacara (PDU), pakaian dinas harian $(\mathrm{PDH})$, pakaian dinas lapangan (PDL), pakaian dinas parade (PDP) serta pakaian dinas sipil harian (PDSH). Adapun seragam Polri yang bersifat khusus antara lain: pakaian dinas samapta, pakaian dinas lalu lintas, pakaian dinas pariwisata, pakaian dinas resers, pakaian dinas intelkam, pakaian dinas brimob, pakaian dinas pol air, pakaian Dinas Pol udara, pakaian dinas satwa, pakaian dinas satpamkol, pakaian dinas satuan musik, pakaian dinas provos, pakaian dinas 
provos, pakaian dinas gadik, pakaian dinas peliputan, pakaian dinas pramugari dan pakaian dinas forensik.

\section{SIMPULAN}

Penggunaan identitas agama seperti penggunaan jilbab dalam lembaga kepolisian khususnya bagi polwan menimbulkan berbagai perdebatan yang alot dan panjang. Karena pada dasarnya tidak terdapat aturan yang tegas dalam pelarangan menggunakan jilbab namun di sisi lain dalam korps Kepolisian terrdapat aturan baku tentang seragam dalam kesatuan yang bertujuan untuk menciptakan ketertiban dan keseragaman di dalam organisasi. Meskipun saat ini polwan telah diperbolehkan untuk menggunakan jilbab ketika bertugas di lapangan, banyak kalangan masih memandang bahwa penggunaan jilbab ini menghambat pelayanan yang diberikan polwan kepada masyarakat.

Penggunaan jilbab bagi polwan sejatinya telah terlebih dahulu diberlakukan bagi polwan yang bertugas di Provinsi Aceh. Penggunaan jilbab bagi polwan di Aceh menguikuti peraturan setempat yaitu syariat islam yang berlaku. Otonomi khusus dan pemberlakuan syariat islam mengharuskan polwan yang beragama islam untuk menggunakan jilbab ketika bertugas. Aturan jilbab bagi polwan di Aceh pada dasarnya bukan berasal dari aturan internal kepolisian, melainkan mengikuti aturan yang dibuat oleh Pemerintah Provinsi Aceh.

Jika ingin menelaah dengan seksama, pelarangan maupun izin untuk menggunakan jilbab bagi polwan yang merupakan bagian dari korps Kepolisian dapat dipandang sebagai penguatan monokulturalisme. Dalam konsep monokulturalisme negara menciptakan penyeragaman melalui hegemoni dalam berbagai berbagai peraturan yang dibuatnya. Perdebatan mengenai jilbab dapat dilihat sebagai tarik-ulur kepentingan negaara yang ingin memisahkan kepentingan agama dari kepentingan negara. Negara dalam hal ini direpresentasikan oleh polwan adalah organisasi yang netral yang tidak boleh menunjukkan identitas personal di hadapan publik dan penyeragaman dalam konteks monokulturalisme adalah sesuatu yang harus ditaati.

\section{REFERENSI}

Bocock, Robert. 2007. Pengentar Komprehensif Untuk Memahami Hegemoni. Yogyakarta: Jala Sutra

El Guindi, Fadwa. 2003. Veil: Modesty, Privacy, and Resistance. Jakarta: Serambi

Hargens, Boni. 2006. Demokrasi Radikal: Memahami Paradox Demokrasi Modern Dalam Perspektif Postmarxis-Ostmodernis Ernesto Laclau Dan Chantal Moufee. LKiS: Yogyakarta

Kymlicka, Will. 2015. Kewargaan Multikultural. Jakarta: LP3ES

Pardoyo. 1993. Sekularisasi dalam Polemik. Jakarta: Pustaka Utama Grafiti

Patria, Nezar. 2009. Antonio Gramsci: Negara dan Hegemoni, Yogyakarta : Pustaka Pelajar

Suseno, Nuri. 2013. Kewarganegaraan, Tafsir Tradisi dan Isu-isu Kontemporer. Departemen Ilmu Politik: FISIP UI

Syaiful, Nilam Hamiddani. 2013. Merebut Kewarganegaraan Inklusif. Yogyakarta: JPP

Thoha, Miftah. 2014. Birokrasi dan Dinamika Kekuasaan. Jakarta: Kencana Prenada Media Group 